\title{
Bare Nature. The Biopolitical Logic of the International Regulation of Invasive Alien Species
}

\author{
Vito De Lucia*
}

This is the post print version (author accepted manuscript) of the paper by the same titled published by the Journal of Environmental Law in 2018

$\underline{\text { https://doi.org/10.1093/jel/eqy016 }}$

\section{KEYWORDS}

Invasive alien species, international environmental law, biopolitics, biodiversity

\section{Introduction}

There is a general and widespread consensus on the negative impacts of invasive alien species on biological diversity. Invasive alien species are indeed considered the 'stock villains of conservation biology', ${ }^{1}$ and are 'commonly recognized as a fundamental threat' ${ }^{2}$ for endemic biological diversity, both terrestrial and marine, ${ }^{3}$ and for agriculture and food security. ${ }^{4}$ Their introduction to novel environments is often described, eloquently, as a biological invasion. ${ }^{5}$

Without invoking science-fiction scenarios as dramatic as the invasion of Earth by the 'red weed', ${ }^{6}$ compelling examples of the destructive effects of invasive alien species are readily available. Paradigmatic cases are the common rabbit in Australia, or the Nile Perch in Africa, but also the king and snow crab in Arctic sea waters. These species invaded a delimited

\footnotetext{
* K. G. Jebsen Center for the Law of the Sea, UiT Arctic University of Norway. Email: vito.delucia@uit.no.

1 Brandon Keim, 'Sometime Invasive Species Are Good' Wired Magazine (New York 28 February 2011) $</$ www.wired.com/2011/02/good-invasives/> accessed 5 June 2018.

${ }_{2}^{2}$ Alexander Gillespie, Conservation, Biodiversity and International Law, (Edward Elgar 2013) 264.

3 ibid., esp. 264ff., and Nicholas Bax and others, 'Marine Invasive Alien Species: a Threat to Global Biodiversity', (2003) 27 Marine Policy, 313.

${ }^{4}$ IPPC Secretariat, Identification of Risks and Management of Invasive Alien Species Using the IPPC Framework, (FAO 2005) x.

${ }^{5}$ Sarah Lowe and others, 100 of the World's Worst Invasive Alien Species. A Selection from the Global Invasive Aliens Species Database (IUCN 2000).

${ }^{6}$ As in the novel HG Wells, The War of the Worlds (first published 1897, OUP 2017).
} 
geographical area. Other invasive alien species however, such as the tiger mosquito, the crazy ant, and the cotton whitefly have spread to almost every corner of the world. ${ }^{7}$

Invasive alien species represent a critical threat to biodiversity as they may determine the decline or elimination of native species - through competition, predation, or transmission of pathogens - and may significantly degrade or radically transform the ecosystems into which they are introduced. ${ }^{8}$ Furthermore, they may spread diseases harmful to humans (as well as to native species of animals and plants), and may cause loss of livelihoods and other negative economic impacts to human communities. According to the Global Biodiversity Outlook 2, invasive alien species played a significant part 'in nearly $40 \%$ of all animal extinctions for which the cause is known', and that have occurred between the $17^{\text {th }}$ century and today. ${ }^{9}$ Moreover, and despite comprehensive international regulation, 'invasive species still wreak havoc on numerous threatened species and ecosystems and have a serious economic impact in all countries'. ${ }^{10}$

There are a number of key elements that are relevant for the identification of introduced species as alien and invasive. First, a species - an animal, a plant, a pathogen or another organism must be alien, in the sense of being non-native of the ecosystem where it is introduced. The introduction, moreover, must have been caused by humans (rather than following a natural pathway), though whether intentionally or not it does not matter. ${ }^{11}$ Secondly, the introduced species must become invasive, that is, it must take root and spread. Finally, it must have a negative impact on native biodiversity. These criteria are useful to understand the notion of invasive alien species operative in international law, and also delimit the scope of this article. ${ }^{12}$ The general response, in both scientific and legal terms is based on prevention and mitigation, with preference - where possible - for complete eradication, if invasion has already occurred. The required approach, additionally, should be systematic. ${ }^{13}$ Importantly, while eradication is not always possible, it remains the primary legally mandated goal for already occurred

\footnotetext{
${ }^{7}$ For a comprehensive report on 100 of the world's worst invasive alien species, see Lowe and others (n 5).

${ }^{8}$ Indeed, they are one of the five main direct causes of biodiversity loss, together with climate change, nutrient loading and pollution, habitat change, and overexploitation.

${ }^{9} \mathrm{CBD}$, Global Biodiversity Outlook 2 (Secretariat of the Convention on Biological Diversity 2006) 35.

${ }^{10}$ As recognized during the IUCN World Conservation Congress, in Honolulu, 2016, see Secretariat of the Convention on Biological Diversity, PRESS RELEASE 'The Honolulu Challenge: an ambitious initiative to tackle the threat of invasive alien species' (29 November 2016) < www.cbd.int/doc/press/2016/pr-2016-11-29HonoluluChallenge-en.pdf> accessed 5 June 2018.

11 It is perhaps useful to clarify that species that migrate or are displaced due to climatic changes or other anthropogenic activities, while susceptible of being regulated through the same biopolitical logic, will not be considered in this article.

${ }^{12}$ For example, species that migrate due for example climatic changes will not be included in the analysis.

${ }^{13}$ Bax and others (n 3).
} 
invasions, and is the primary focus of the biopolitical 'problematization' carried out in this article. It is perhaps useful to mention that in using the term problematization I find inspiration in the work of Michel Foucault, and his use of the term. Problematizations, for Foucault, are ways of questioning or unpacking 'domain of acts, practices, and thoughts that seem [...] to pose problem for politics' ${ }^{14}$ (or, in our case, to law). The goal of a problematization is not, however, to arrive at a 'just or definitive solution', ${ }^{15}$ but rather to open up, to question, to explore a problem (invasive alien species), and the solutions developed to address it (eg the international regulatory framework and the practices it enables).

This article, adopting a critical environmental legal perspective, ${ }^{16}$ shows how this approach to the problem of invasive alien species responds to a biopolitical logic of governing environmental problems that, in multiple ways, seem to shape the entire architecture and orientation of international environmental law. ${ }^{17}$ This mechanism is arguably also at play in other contexts, such as food production, where pests are systematically killed in order to defend plants and animals grown and bred to become human food. ${ }^{18}$ However, here the distinctive trait is that the focus is on the protection of nature (that is, biodiversity) on its own terms, shifting the question on a more directly ecological terrain, with the key implication that it falls more squarely within the specific purview of international environmental law.

In order to articulate my argument, I will draw on three key theorists: Michel Foucault, who first fully articulated the concept of biopolitics; and then Giorgio Agamben and Roberto Esposito, who further elaborated biopolitics in interesting directions, and from which I will draw primarily two ideas. From Agamben I will draw the idea of bare life (which I will rearticulate as bare nature $){ }^{19}$ from Esposito, the idea that biopolitics is driven by an immunitary logic with aporetic consequences. ${ }^{20}$ The key dilemma of biopolitics is, as I will show, the continuous transformation of a politics of life into a politics of death. ${ }^{21}$ The regulation

\footnotetext{
${ }^{14}$ Michel Foucault, 'Polemics, Politics and Problematizations', Interview by Paul Rabinow, May 1984, in Michel Foucault, Ethics: Subjectivity and Truth. Essential Works of Foucault Vol. 1, The New Press, 1998, p. 114

${ }^{15}$ Ibid. p. 114

${ }^{16}$ On Critical environmental law e.g. Andreas Philippopoulos-Mihalopoulos, 'Towards a Critical Environmental Law' in Andreas Philippopoulos-Mihalopoulos (ed) Law and Ecology. New Environmental Foundations (Routledge 2011), as well as Vito De Lucia, 'Critical Environmental Law and the Double Register of the Anthropocene. A Biopolitical Reading' in Louis Kotzè, Environmental Law and Governance in the Anthropocene (Hart Publishing 2017).

${ }^{17}$ See e.g. Vito De Lucia, 'Beyond Anthropocentirsm and Ecocentrism. A Biopolitical Reading of Environmental Law' (2017) 8 JHRE 181.

${ }^{18}$ See in this respect already the 1902 Convention for the Protection of Birds Useful to Agriculture (IPE Vol IV, 16153 , (1902), 177), which distinguishes between useful and noxious birds, hence discerning between which life to protect and which to eliminate.

${ }^{19}$ Giorgio Agamben, Homo Sacer. Sovereign Power and Bare Life (Stanford UP 1998).

${ }^{20}$ Roberto Esposito, Bios: Biopolitics and Philosophy (Minnesota UP 2008).

21 ibid 39.
} 
of invasive alien species is in this respect a particular efficacious example of this biopolitical dilemma, as the distance between a politics of life and a politics of death is arguably in no other regulatory contexts as thin. Never as clearly and immediately as in relation to invasive alien species, law in the same gesture protects life and produces death. Invasive alien species, I will argue, are thusly transformed into bare nature, cast into what Agamben calls a 'zone of irreducible indistinction', ${ }^{22}$ where inclusion and exclusion, law and violence, life and death, co-exist simultaneously, and where invasive alien species can be killed with impunity.

Moreover, death is legitimated on the basis of the protection of life. The legitimacy of the interventions aimed at eradicating invasive alien species by way of eg poisons or snipers, rests on the biopolitical logic of eradications: ensuring the survival of threatened endemic species. This double effect of a single gesture, I suggest, enacts precisely what Roberto Esposito has called the aporetic logic of biopolitics. ${ }^{23}$

This article shall endeavour to show the manner in which this logic operates, and the problematics it raises. The aim of this article is, obviously, not to question the need to regulate, in some way, invasive alien species, and to prevent or minimize the complex array of their negative effects. The aim is, rather, to problematize the biopolitical logic that underpins the practices of control and eradication of invasive alien species that, often enough, culminate in mass killings carried out in the name of life.

The article will proceed as follows. Section 2 will give an outline of the relevant international legal framework regulating invasive alien species. The aim of this section is to show how the regulation of invasive alien species, and its underlying biopolitical logic, is coherently replicated across the different legal and regulatory contexts that constitute the international biodiversity regime, and how eradication is the primary approach once an invasion has occurred. Section 3 will present a biopolitical framework of analysis, consisting of both a theory and a method of inquiry. Section 4 will deploy the biopolitical framework in relation to the legal regulation of invasive alien species, in order to show how law enacts the aporetic logic of biopolitics. Section 4, in order to further illustrate the mechanics of this biopolitical logic, will also offer some concrete cases showing how the fostering of life and the production of death, inextricably intertwined, emerge as two opposite yet simultaneous consequences of the same legal and material gesture. Finally, in section 5 I offer some concluding remarks.

\footnotetext{
${ }^{22}$ Agamben, (n 19) 12.

${ }^{23}$ Ibid.
} 


\section{The Regulation of Invasive and Alien Species in International Biodiversity Law}

This section gives an illustrative overview of the regulation of invasive alien species in international biodiversity law. The intent is not to be detailed and comprehensive, nor to interpret treaty provisions. The goal is that of showing the overall logic underpinning the international regulation of invasive alien species, a logic which I will read in biopolitical terms. In this respect, this section wishes to illustrate how invasive alien species are regulated rather uniformly across diverse legal regimes and institutional contexts as a threat to biological diversity. The overall purpose of this section, in other words, is to show the coherence of the international legal regime regulating invasive alien species in international biodiversity law, and how the relevant rules operate as both a discourse and a practice enacting the biopolitical logic that I will illustrate in section 3.

At the most general level, there is a number of general international legal obligations relevant for the regulation of invasive alien species, linked to the sic utere tuo ut alienum non laedas principle. These general obligations of good neighbourliness and no-harm emerged in an international environmental context with the Trail Smelter Arbitration, ${ }^{24}$ and have now consolidated into a general principle of international law. ${ }^{25}$ Other, more recent principles, regulate in general terms activities of States that may have negative effects on the environment (domestic, regional or global). Such are the principle of prevention, ${ }^{26}$ the principle of precaution, ${ }^{27}$ and the principle of environmental impact assessment. ${ }^{28}$ Under these general

\footnotetext{
${ }^{24}$ Trail Smelter Case, (United States v. Canada) (1938 and 1941) 3 R.I.A.A. 1905.

25 'The existence of the general obligation of States to ensure that activities within their jurisdiction and control respect the environment of other States or of areas beyond national control is now part of the corpus of international law relating to the environment', ICJ, Legality of the Threat or Use of Nuclear Weapons, [1996] ICJ Reports 226 [29]; but see also eg the Corfu Channel case [1949] ICJ Reports 4, the Lake Lanoux Arbitration (France v. Spain) [1957] 12 RIAA 281 and the Iron Rhine Arbitration [2005] ICGJ 373 [PCA 2005] as well as ILC, Draft Articles on Responsibility of States for Internationally Wrongful Acts, with Commentaries, Yearbook of the International Law Commission, vol. II, Part Two. 2001.

${ }^{26}$ ILC, Draft Articles on Prevention of Transboundary Harm from Hazardous Activities (hereinafter Draft Articles on Prevention), Article 3, United Nations Convention on the Law of the Sea, 1833 UNTS 3 (1982) (hereinafter UNCLOS) art. 194; United Nations Framework Convention on Climate Change, 1771 UNTS 107 (1992) (hereinafter UNFCCC) art. 3.

${ }^{27}$ Principle 15, Rio Declaration on Environment and Development, U.N. Doc. A/Conf.151/26 (Vol. I); Preamble, Convention on Biological Diversity, 1760 UNTS 79 (1992) (hereinafter CBD); UNFCCC, article 3; For relevant case law, see ICJ cases such as Gabcikovo-Nagymaros Project [1997] ICJ Reports 7, Pulp Mills on the River Uruguay [2010] ICJ Reports 14..

${ }^{28}$ Principle 17, Rio Declaration; Convention on Environmental Impact Assessment in a Transboundary Context, 1989 UNTS 309 (1991); Gabcikovo-Nagymaros (n 27) [140]; Pulp Mills (n 27) [203]. UNCLOS articles 204-206 deals specifically with impact assessment related to invasive alien species. Finally, we shall see later in this section the most relevant rules laid out in the CBD as regards environmental impact assessment and pertaining to invasive alien species.
} 
principles (which are increasingly included in treaties), ${ }^{29}$ States shall prevent that activities under their jurisdiction or control (such as those activities that may determine the introduction of an alien species) cause harm to the environment of other states, or of areas beyond national jurisdiction.

Specific regulation of invasive alien species however, has been introduced with varying levels of stringency in a variety of Multilateral Environmental Agreements (MEAs) and is now an important part of the international biodiversity regime. The latter is comprised of a multiplicity of different conventions and other international agreements. While the most important is arguably the CBD, together with its two Protocols, ${ }^{30}$ the broader regime includes the Convention on Conservation of Migratory Species of Wild Animals (CMS), ${ }^{31}$ the Convention on Wetlands of International Importance especially as Waterfowl Habitat (Ramsar Convention), ${ }^{32}$ the Convention on International Trade in Endangered Species of Wild Fauna and Flora (CITES), ${ }^{33}$ the International Treaty on Plant Genetic Resources for Food and Agriculture (Plant Treaty), ${ }^{34}$ and the Convention Concerning the Protection of the World Cultural and Natural Heritage. ${ }^{35}$

It is precisely the specific rules establishing guidelines and policy preferences for dealing with the invasive alien species problem within the context of the international biodiversity regime that are of interest for the purposes of this article (rather than the broader, more general and often customary rules regulating interstate relations mentioned above). This is because they delineate a science-based policy approach that embody the biopolitical logic I shall present in section 3, and how it articulates the relation between law and nature. I shall focus especially (though not exclusively) on how eradication is the primary principle and policy tool to deal with biological invasions once they have occurred.

${ }^{29}$ Eg CBD (n 27) preamble, UNCLOS (n 26), article 194(2); UNFCCC (n 26), art. 3; ILC Draft Articles on Prevention (n 26), art. 3

${ }^{30}$ The Cartagena Protocol on Biosafety to the Convention on Biological Diversity, 2226 UNTS 208 (2000); (hereinafter Cartagena Protocol) and the Nagoya Protocol on Access to Genetic Resources and the Fair and Equitable Sharing of Benefits Arising from their Utilization to the Convention on Biological Diversity, 31 ILM 818 (2010). (hereinafter Nagoya Protocol).

${ }^{31}$ Convention on Conservation of Migratory Species of Wild Animals, 1651 UNTS 333 (1979) (hereinafter CMS Convention). See esp. articles 4 (c) and 5(e).

${ }^{32}$ Convention on Wetlands of International Importance especially as Waterfowl Habitat, 996 UNTS 245 (1971) (hereinafter RAMSAR Convention). See esp. Resolution VII.14 (1999) and VIII.18 (2002) both entitled 'Invasive Species and Wetlands'.

${ }^{33}$ Convention on International Trade in Endangered Species of Wild Fauna and Flora, 993 UNTS 243 (1973) (hereinafter CITES). See esp. Resolution Conf. 13.10 (Rev. CoP14), 'Trade in Alien Invasive Species'.

${ }^{34}$ International Treaty on Plant Genetic Resources for Food and Agriculture, 2400 UNTS 303 (2001) (hereinafter Plant Treaty).

${ }^{35}$ Convention Concerning the Protection of the World Cultural and Natural Heritage, 1037 UNTS 151 (1972) (hereinafter Heritage Convention). 


\subsection{Defining Invasive Alien Species}

The first important task is to understand and define the concept of invasive alien species. The CBD is a good starting point. Article $8(\mathrm{~h})$ refers to alien species 'that threatens ecosystems, habitats or species'. ${ }^{36}$ An alien species, in turn, is a 'species, subspecies or lower taxon, introduced outside its natural past or present distribution; includes any part, gametes, seeds, eggs, or propagules of such species that might survive and subsequently reproduce'. ${ }^{37}$ An invasive and alien species, still according to CBD's definitions, 'means an alien species whose introduction and/or spread threaten biological diversity'. ${ }^{38}$ The element that makes an alien species invasive is thus the potential for harm.

There is a multiplicity of pathways through which alien species can be introduced to new environments and ecosystems. Identification of such pathways is a key element of the regulation of invasive alien species. These pathways are linked to both intentional and unintentional, or accidental, introductions. Unintentional, or accidental, introductions occur as an unintended consequence of human activities. Typical cases of accidental introductions include transport of species by way of ballast water, so-called marine bio-fouling (which includes hull fouling and clingages), civil air transport, military activities, scientific research and a variety of conveyances (vessels, floating timber, packaging and containers, tourist vessels etc.). ${ }^{39}$ Intentional introductions are most often linked to economic gain and recreational activities, but also with environmental stewardship. Examples abound: the introduction of species with the aim of establishing a fur trade $;^{40}$ the introduction of alien tree species in many countries, with the aim of establishing a profitable commercial timber crop; ${ }^{41}$ the introduction of many fish species for angling or aquaculture; ${ }^{42}$ the introduction of species to prevent soil

\footnotetext{
${ }^{36}$ CBD (n 27), Article 2

37; 'invasive alien species', in turn, refers to alien species 'whose introduction and/or spread threaten biological diversity', Decision VI/23, 'Alien species that threaten ecosystems, habitats or species' (2002) $\mathrm{UNEP} / \mathrm{CBD} / \mathrm{COP} / 6 / 20,257$, footnote 57 , letter (i).

${ }^{38}$ Decision VI/23 (n 37) 257, footnote 57 letter (ii). The expressions 'invasive alien species' and 'alien invasive species' are to be considered equivalent, ibid.

${ }^{39}$ For a more comprehensive list see COP Decision VIII/27, 'Alien species that threaten ecosystems, habitats or species (Article $8(\mathrm{~h})$ ): further consideration of gaps and inconsistencies in the international regulatory framework', adopted by the Conference of the Parties to the Convention on Biological Diversity at its eighth meeting, Curitiba, Brazil, 20-31 March 2006, UNEP/CBD/COP/DEC/VIII/27.

${ }^{40}$ Lowe and others (n 5); see also Claire Shine, Nattley Williams and Lothar Gündling, A Guide to Designing Legal and Institutional Frameworks on Alien Invasive Species (IUCN 2000), UNEP/CBD/SBSTTA/6/INF/8.

${ }^{41}$ Lowe and others (n 5); Shine, Williams and Gündling however consider these species as remaining under human control, thus not to be included in the category of invasive alien species so long as they do not establish themselves in the wild, (n 40) 2.

${ }^{42}$ Lowe and others (n 5); Shine, Williams and Gündling (n 40).
} 
erosion, or to operate as biological controls against other invasive alien species; ${ }^{43}$ finally, the introduction of species as pets, or as farm animals. Escapes in the wild may lead in these cases to the establishment of such species in the new environments and their becoming, thusly, invasive.

\subsection{The Regulation of Invasive Alien Species in the Convention on Biological Diversity}

The primary rule governing the regulation of invasive alien species within the CBD regime is contained in article 8(h). The provision sets out that State parties shall, 'as far as possible and as appropriate' prevent the introduction of alien species, or where not possible, shall 'control or eradicate those alien species which threaten ecosystems, habitats or species'. This primary rule has been further elaborated, in order to facilitate its implementation, in a number of decisions of the Conference of the Parties (COP) to the CBD, particularly by way of developing and adopting implementing principles, technical guidelines and action plans, as shown below. This was necessary in light of the fact that the CBD is a process-oriented ${ }^{44}$ framework $^{45}$ Convention, and thusly sets out general rules that impose obligations on States, yet these rules and obligations need to be implemented domestically by specific national invasive alien species strategies and action plans. ${ }^{46}$ Technical and policy guidelines documents are in this respect an important element to help facilitate domestic implementation, share best practices, and ensure a harmonized policy approach.

As a testimony to the importance of the issue, at its fourth meeting the COP established invasive alien species as a cross-cutting issue of the CBD. At its sixth meeting, the COP adopted Decision VI/23 (2002) on 'Alien species that threaten ecosystems, habitats or species'. ${ }^{47}$ After recognizing how invasive and alien species are one of the 'primary threats to biodiversity', ${ }^{48}$ the decision adopted a set of guiding principles 'for the Prevention, Introduction and Mitigation

\footnotetext{
${ }^{43}$ Lowe and others (n 5); Shine, Williams and Gündling (n 40).

44 Thus Viet Koester, 'The Biodiversity Convention Negotiation Process and Some Comments on the Outcome', (1997) 27 Environmental Policy and Law 175, 187.

${ }^{45}$ In the double sense of establishing general principles to be further specified in implementation Protocols, and of leaving implementation decisions and modalities to the individual parties, see eg Lyle Glowka and others, A Guide to the Convention on Biological Diversity ( $3^{\text {rd }}$ edition, IUCN 1994) 1. For a partially divergent opinion see however Adalheidur Johannsdottir, 'The Convention on Biological Diversity. Supporting Ecological Sustainability or Prolonging Denial?' (2010) 1 Nordic Env L J, 81; which argues that the CBD is a 'mixture of a framework convention and a conventional one', 85.

${ }^{46}$ See e.g. Decision VI/23 (n 37) para 10.

${ }^{47}$ Ibid.

${ }^{48}$ And especially 'in geographically and evolutionary isolated ecosystems, such as small island developing States', Decision VI/23 (n 37) para 1, Section II.
} 
of Impacts of Alien Species that Threaten Ecosystems, Habitats or Species'. ${ }^{49}$ These include the precautionary approach, ${ }^{50}$ the crucial role of States in relation to their responsibility for activities within their jurisdiction and control, ${ }^{51}$ and the continued focus on mitigation of impacts. ${ }^{52}$ Additionally, and $\mathrm{n}$ importantly for the purposes of this article, the eradication of invasive and alien species is considered, where feasible, 'often the best course of action'. ${ }^{53}$ Subsequent COP decisions focused successively on in-depth reviews of ongoing work on alien species threatening ecosystems, habitats or species $;{ }^{54}$ on options for reform $;{ }^{55}$ on encouraging transboundary cooperation; ${ }^{56}$ on ways and means to address gaps in international standards, with particular references to those invasive alien species originally introduced either as pets, as aquarium and terrarium species, or as live bait and live food. ${ }^{57}$ Following up on this last decision, in 2014, the COP at its twelfth meeting adopted a voluntary 'Guidance on devising and implementing measures to address the risks associated with the introduction of alien species as pets, aquarium and terrarium species, and as live bait and live food' ${ }^{58}$ The aim of the guidance is that of assisting countries and other relevant organizations with the management of the risks associated with these particular pathways of invasion, categorized as 'escape' from captivity or otherwise confined conditions. The guidance contains a number of thematic areas, including risk assessment, risk management, suggested measures and information sharing. Particularly interesting for the purposes of this article is the last of the suggested measures to prevent escape. Paragraph 20 suggests in fact that consignments 'may be labelled as 'potential hazard to biodiversity', a significant terminological choice, with clear resonances with the frame of biosecurity, an important biopolitical marker, as we will see.

The CBD also offers guidelines for environmental impact assessment, an important tool for the regulation of invasive alien species. In this respect, invasive alien species are to be considered

${ }^{49}$ Decision VI/23 (n 37) Annex 'Guiding Principles for the Prevention, Introduction and Mitigation of Impacts of Alien Species that Threaten Ecosystems, Habitats or Species' (hereinafter 'Guiding Principles').

50 'Decision VI/23 (n 37) Guiding Principles', Section A, Principle 1.

51 'Decision VI/23 (n 37) 'Guiding Principles', Section A, Principle 4.

52 'Decision VI/23 (n 37) 'Guiding Principles', Section D.

53 'Decision VI/23 (n 37) 'Guiding Principles', Section D, Principle 13, emphasis added.

${ }^{54}$ Decision IX/4, 'In-depth review of ongoing work on alien species that threaten ecosystems, habitats or species', (2008) UNEP/CBD/COP/DEC/IX/4.

55 Ibid.

${ }^{56}$ Decision X/38, 'Invasive alien species' (2010) UNEP/CBD/COP/DEC/X/38.

${ }^{57}$ Decision XI/28, 'Invasive alien species' (2012) UNEP/CBD/COP/DEC/XI/28.

${ }^{58}$ Decision XII/16, 'Invasive alien species: management of risks associated with introduction of alien species as pets, aquarium and terrarium species, and as live bait and live food, and related issues' (2014) UNEP/CBD/COP/DEC/XII/16. 
direct drivers of change, ${ }^{59}$ and one of the key factors affecting biodiversity. ${ }^{60}$ Moreover, CBD Guidelines on the impacts of invasive alien species, albeit non-binding, sets out, at principle $4.1,{ }^{61}$ that States should recognize the risks related to invasive aliens species that activities under their jurisdiction and control may pose to other States. As we shall see later in more detail, while the guidelines on environmental impact assessment in relation to invasive alien species suggest that prevention is the key priority, the crucial element of interest for the purpose of this article is that once an introduction has taken place, the "preferred response is often to eradicate the organisms as soon as possible' ${ }^{62}$

A further important element in relation to invasive alien species in the regime set out within the context of the CBD is represented by the Aichi Targets, which are a set of 20 measurable targets adopted within the context of the Strategic Plan for Biodiversity, and to be met by the year 2020. ${ }^{63}$ Aichi target 9 in particular is dedicated to invasive alien species, in light of their role as 'direct driver of biodiversity loss', ${ }^{64}$ and of their being a cross-cutting issue under the CBD. Aichi target 9 sets out the goal of, by 2020, identifying and prioritizing invasive alien species and their introduction pathways; of controlling or eradicating priority species; and of putting in place measures to manage pathways, in order to prevent alien species' introduction and establishment. ${ }^{65}$ This target has been reiterated in the recently adopted global sustainable development goals (SDG). In particular, SDG 15.8 sets out the objective of introducing, by 2020, 'measures to prevent the introduction and significantly reduce the impact of invasive alien species on land and water ecosystems and control or eradicate the priority species' ${ }^{66}$

The target, also reflected in the regulation of invasive alien species more broadly, ${ }^{67}$ has a twofold focus. On the one hand, and as far as possible, management should focus on introduction pathways, that is, on prevention. On the other hand, identified invasive alien species must be controlled or, most importantly for the purposes of the present article,

${ }^{59}$ That is, those 'biophysical changes that may influence the composition or structure of ecosystems, or influencing key processes maintaining these ecosystems', Roel Slootweg and others, Biodiversity in EIA and SEA. Background Document to CDB Decision VIII/28, Voluntary Guidelines on Biodiversity-inclusive Impact Assessment (Commission on Environmental Assessment 2006) 57.

60 Ibid.

${ }^{61}$ Decision VI/23 (n 37).

${ }^{62}$ Decision VI/23 (n 37), Guiding Principle 2, para 2, emphasis added. See also Principle 13, named 'Eradication'

${ }^{63}$ Decision X/II, 'Strategic Plan for Biodiversity 2011-2020' (2010) UNEP/CBD/COP/DEC/X/2

${ }^{64}$ CBD, Achieving Aichi Biodiversity Target 9 (Secretariat of the Convention on Biological Diversity 2015$) 3$.

${ }^{65}$ Decision X/II (n 63) Annex, Section IV.

${ }^{66}$ SDG 15.8, UNGA Resolution 'Transforming our world: the 2030 Agenda for Sustainable Development' (2015) A/RES/70/1, 35ff.

${ }^{67}$ See eg CBD (n 27) article 8(h) as well as Decision VI/23 (n 37), but also more in general the principle of prevention. 
eradicated.$^{68}$ Once species and pathways have been identified, an important part of the process of managing, in the broadest sense of the term, invasive alien species lies in the prioritization of both species and pathways. Only after prioritization countries should move on with the decision of whether the species in question should be controlled or eradicated (a decision that hinges on a number of relevant factors to be evaluated on a case-by-case basis).

\subsection{Invasive Alien Species in Other Biodiversity-related Treaty- regimes}

As mentioned, the CBD, while central, is not the only regime that sets out rules for the regulation of invasive alien species. In this respect, it will be useful and necessary to offer a very brief, and only illustrative (that is, non-exhaustive) overview of other relevant treaties and treaty-regimes that focus on biodiversity. This will allow to underline further the consistent focus on eradication as a key tool to deal with invasive alien species.

The $\mathrm{CMS}^{69}$ regulates exotic species that may endanger migratory species. The main rule is that range State parties should strive ('to the extent feasible and appropriate', article III.4.c) to strictly control the introduction of exotic species, or, where already introduced, control or eliminate them. ${ }^{70}$ Relatedly, the Agreement on the Conservation of Albatrosses and Petrels (ACAP), ${ }^{71}$ a multilateral environmental agreement adopted under article IV of the CMS, has adopted specific rules and guidelines aimed at the control and eradication of invasive alien species threatening ACAP's target species. In 2008 ACAP adopted in this respect 'Guidelines for eradication of introduced mammals from breeding sites of ACAP-listed seabirds' ${ }^{72}$ The guidelines recognize how 'the islands on which ACAP species breed are usually sufficiently isolated that eradication is a practical option', ${ }^{73}$ and layout general guidelines for the successful implementation of eradication programs.

The Ramsar Convention has adopted two resolution in relation to invasive species and wetlands, ${ }^{74}$ and a background document on invasive species and wetlands, ${ }^{75}$ outlining definitions, effects of invasive alien species on the ecological character of wetlands and of wetlands' species, methods of control and the roles of various relevant entities and organizations (states, NGOs, Ramsar Convention etc.). Invasive alien species are recognized

\footnotetext{
${ }^{68}$ Though control has also a clear biopolitical inflection, as we shall see.

${ }^{69}$ CMS Convention (n 31).

${ }^{70}$ Similar language is used in article III.4.c. and in Annex II, article V.4.

${ }^{71}$ Agreement on the Conservation of Albatrosses and Petrels, 2258 UNTS 257 (2001) (hereinafter ACAP).

${ }^{72}$ Richard Phillips, 'Guidelines for eradication of introduced mammals from breeding sites of ACAP-listed seabirds' <www.acap.aq/images/stories/PDF_Docs/En/acap_eradication_guidelines_e.pdf> 'accessed 5 June 2018.

$73 \mathrm{ibid}$, there is no page number in the document.

${ }^{74}$ Resolution VII.14 (n 33)

${ }^{75}$ Ramsar Convention, COP7 DOC. 24.
} 
as posing a 'severe threat $[\ldots]$ to the ecological character of wetlands, and to wetland species, terrestrial and marine' ${ }^{76}$ and that, furthermore, 'invasions can cause major social and economic damage and loss' ${ }^{77}$ The main actions to be taken under the Ramsar Convention are related, inter alia, to the preparation of inventories of invasive alien species in wetlands areas on the part of State parties; to the preparation of programmes of control and eradication of priority invasive alien species; and to review existing and prepare new legislation related to "new and environmentally dangerous alien species'. ${ }^{78}$ The Ramsar Convention has also cooperated with the CBD on matters related to invasive alien species (through a memorandum of cooperation and a Joint Ramsar-CBD Work Plan endorsed with COP Decision IV/15), as well as with $\mathrm{IUCN}^{79}$ and the Global Invasive Species Programme. ${ }^{80}$

This brief and illustrative overview was aimed at showing how invasive alien species are regulated coherently across the international biodiversity regime. The main point to take home from this overview is precisely how there exists a broad conceptual and normative consensus on the need to prevent and control, but most importantly for the purposes of this article, eradicate invasive alien species. As I will endeavour to show in the rest of the paper, it is precisely the logic underpinning the specific concretization of this consensus in positive international law that is susceptible of a biopolitical reading and critique.

\section{A Biopolitical Framework of Analysis}

\subsection{Introduction}

The preceding sections has given an illustrative overview of the regulation of invasive alien species in international biodiversity law, by way of interrogating a number of specific legal regimes. The goal was to show in broad strokes the consistency, across regimes, of the key rules and principles regulating invasive alien species, of the goal of such regulation, and, especially, of the key methods adopted or suggested to address the issue. In the rest of this article, I shall argue that this legal strategy is expression of a specific modality of power and is underpinned by a specific logic. This modality of power is biological and aims a fostering life through a biopolitical logic. Yet this biopolitical logic, and this is a key part of my argument,

\footnotetext{
${ }^{76}$ Resolution VII.14 (n 33) para 1.

${ }^{77}$ Resolution VIII.18 (n 33 para 1.

${ }^{78}$ Resolution VII.14 (n 33) para 18.

79 IUCN is one of Ramsar's International Organization Partners, <http://archive.ramsar.org/pdf/moc/MoC_5IOPs_19-5-11_SIGNED.pdf> accessed on 6 june, 2018. See also Resolution VII.14 (n 33), para 9, 10 and 16

${ }^{80}$ See Resolution VII.14 (n 33), para 9
} 
is affected by a crucial dilemma, as the protection of life is only possible, it appears, at the cost of killing (other) life through a sovereign command. What the biopolitical logic tells us then, is that life and death are inevitably entangled and are the simultaneous results of the same gesture.

As the first step in the theoretical problematization of the international regulation of invasive alien species, this section introduces the analytical and theoretical framework of biopolitics. This section will thus introduce some key concepts, such a biopower and biopolitics, and subsequently discuss the relation between biopolitics and sovereignty, and the manner in which a biopolitical framework of analysis can be usefully deployed with specific reference to the conservation of biodiversity in general, and the regulation of invasive alien species in particular.

\subsection{Biopower and Biopolitics}

While the history of biopolitics, with its multiple lines of elaboration, is complex to trace, a usual starting point is the work of French political philosopher Michel Foucault. In Foucault's thought, biopolitics is one of two modes of operation of a new form of power that seizes life under its purview: biopower. ${ }^{81}$ It is from biopower, then, that we must start. Biopower is the endpoint of a shift in discursive and operative emphasis from a sovereign and negative, to a biological and positive mode of power. Sovereign power, argues Foucault, takes primarily the form of a 'deduction' or 'subtraction'; 82 it operates negatively by way of removing, taking away, extracting, or appropriating resources ('a portion of the wealth, a tax of products, goods and services, labour and blood', and, also, life) away from a subject. ${ }^{83}$ In the last chapter of the first volume of his 'History of Sexuality', ${ }^{84}$ and further in the lectures gathered under the title 'Society Must be Defended' ${ }^{85}$ Foucault notes how sovereign power finds its paradigmatic expression in a right to kill, so that sovereignty is, ultimately, the 'power of life and death'. ${ }^{86}$ Biopower on the other hand, takes life under its care, and operates according to two trajectories: one of legitimation (power finds legitimacy through caring for life), and one of control (power

\footnotetext{
${ }^{81}$ Michel Foucault, The History of Sexuality. Volume I: an Introduction (Pantheon Books 1978).

82 ibid 136.

83 ibid 136.

${ }^{84}$ ibid. However, the very first outline of biopower was originally contained in La Volonté de Savoir, whose third part was entitled 'Right of Death and Power over Life', a part which was subsequently reproduced in English translation in Foucault (n 80), see eg Timothy Campbell and Adam Sitze (eds) Biopolitics. A Reader (Duke UP 2013) 3-4.

${ }^{85}$ Foucault (n 81).

86 ibid 136.
} 
'distribut[es] the living in the domain of value and utility'). ${ }^{87}$ Unlike sovereign power, which becomes manifest with the taking of life, biopower qualifies, measures, appraises and hierarchizes, with the ultimate aim of fostering life. ${ }^{88}$

Biopower is comprised of two poles, or modes. The first relates to the emergence of technologies of power 'essentially centered on the body', ${ }^{89}$ which Foucault understands as disciplines, or as the 'anatomopolitics of the human body'. ${ }^{90}$ These technologies are aimed at disciplining the individual body, in order to extract its forces and to increase 'its usefulness and its docility'. ${ }^{91}$ Ultimately disciplines aims at the 'surveillance' of individual bodies, ${ }^{92}$ and at their integration 'into systems of efficient and economic controls'. ${ }^{93}$

Foucault, however, identifies a second mode of operation of biopower. If in its anathomopolitical articulation, biopower aims at governing and disciplining the body, the specific goal of this second operative mode(l) - biopolitics - is that of governing life's broad processes. Unable to control individual life, its sicknesses and the modalities and timings of individual deaths, biopolitics focuses on populations, and thus aims at controlling life as a set of biological processes: ${ }^{94}$ 'propagation, births and mortality, the level of health, life expectancy and longevity, with all the conditions that can cause these to vary'. ${ }^{95}$

Life, this is the goal of biopolitics, can be regularized; its processes predicted and optimized. With particular respect to the environment (and I will return in more details on this point in section 3.4), of central relevance is the fact that through biopolitics nature is no longer simply an object of sovereign exploitation, ${ }^{96}$ but becomes subjected to a series of positive interventions that aim at its care, at fostering and optimizing its processes, and at the same time at the enhancement of its productive forces. ${ }^{97}$ In this respect the transition from sovereign power to biopower tracks rather well the evolution of international law in the field of the environment, considering how the barycentre has arguably moved over time from the principle of permanent

\footnotetext{
87 ibid 144.

88 ibid 144.

${ }^{89}$ Michel Foucault, Society Must Be Defended. Lectures at the Collège de France 1975-1976 (Penguin 2003 ) 242.

${ }^{90}$ Foucault (n 81) 139, emphasis in the original.

91 ibid 139.

${ }^{92}$ Foucault (n 89) 242.

${ }^{93}$ Foucault (n 81) 139.

${ }^{94}$ Foucault (n 89) 246.

${ }^{95}$ Foucault (n 81) 139.

${ }^{96}$ Here there is a crucial slippage with respect to the notion of anthropocentrism, albeit there is still an overlap with notions of stewardship. Indeed, pastoral care, in Foucault's reconstruction, was a crucial precursor of biopolitics, see Michel Foucault, Security, Territory, Population: Lectures at the Collège de France, 1977-1978 (Palgrave Macmillan 2009).

${ }^{97}$ Thomas Lemke, Biopolitics. An Advanced Introduction (New York UP 2011) 68, See also more generally Michael Hardt, and Antonio Negri, Empire. The New World Order (Harvard UP 2000).
} 
sovereignty over natural resources to duties of conservation and sustainable use. The latter duties today arguably limit sovereignty and shift the emphasis on a positive exercise of power whose interventions must conserve and foster life.

Biopolitics is comprised of a set of 'regulatory mechanisms" ${ }^{\text {'9 }}$ or 'controls' 99 whose goal is to achieve 'an equilibrium, maintain an average, establish a sort of homeostasis, and compensate for variations within' ${ }^{100}$ what is generally understood as an 'aleatory field'. ${ }^{101}$ Biopolitics, ultimately, attempts to achieve the 'calculated management of life', ${ }^{102}$ and, what is more important in the context of this article, the calculated management of nature, as will be discussed in section 3.4.

Foucault's thought on biopower and biopolitics offers arguably an enticing theoretical framework to critically approach contemporary (international) environmental law. ${ }^{103}$ In the context of this article however, Foucault's approach will require significant integration. Subsequent elaborations have in fact caught and tried to fill an important gap in Foucault's thought on biopower, namely the relation between biopower (as a positive form of power) and sovereignty. Indeed, the idea of sovereign command, I will argue by drawing especially on Giorgio Agamben and Roberto Esposito, remains a key element of biopower. Albeit often in the background, sovereignty - and its negative mode of power - remains always capable of reactivation, any time that is necessary to protect life. The key shift however, is that the sovereign command that takes life, after the advent of biopower, is only legitimate if killing saves life. Law has in this context a key role to play, as both its conceptual approach on invasive alien species and its operational effects arguably are underpinned by a biopolitical modulation of the sovereign command. The next section will discuss precisely the relation between biopower and the sovereign command.

\subsection{Sovereign Command and Biopolitics}

In Foucault's theoretical framework, the relation between sovereign power and biopower is not well articulated, and is not always coherent or consistent. Italian political philosophers have criticized this wavering aspect of Foucault's thought, and have offered sophisticated contributions aimed at (re)establishing a key continuity between sovereign power and biopower.

\footnotetext{
${ }^{98}$ Foucault (n 89) 246.

${ }^{99}$ Foucault (n 81) 139.

${ }^{100}$ Foucault (n 89) 246.

101 ibid 246.

${ }^{102}$ Foucault (n 81) 140.

${ }^{103}$ De Lucia (n 17).
} 
While biopower and biopolitics are closely related, from this point on I will mostly use biopolitics, given that is the central term of the two Italian philosophers whose contribution to the theory of biopolitics I will discuss.

The two Italian philosophers whose contribution to a theory of biopolitics are Giorgio Agamben and Roberto Esposito. Agamben criticizes Foucault (and most modern and contemporary political philosophy) for having missed the 'hidden point of intersection' between sovereign and biopolitical models of power. ${ }^{104}$ Esposito, similarly, emphasizes decisively the continuity between sovereignty and biopolitics, biology and politics, speaking of a 'logic of copresence' that in fact he sees already at work in Foucault's thought, but only on occasion and outside of any coherent or systematic articulation, ${ }^{105}$ due to what he characterizes as a 'fundamental indecisiveness' on the part of Foucault. ${ }^{106}$

A comprehensive discussion of these elaborations clearly exceeds the scope of this article, so I will only discuss two key concepts that are particularly relevant for our context: Agamben's concept of 'bare life', and Esposito's concept of 'immunity'.

Agamben, as anticipated, criticizes Foucault's seeming discontinuous understanding of sovereign power and biopower. He suggests by contrast that 'the two analyses cannot be separated and that the inclusion of bare life in the political realm constitutes the original - if concealed - nucleus of sovereign power' ${ }^{107}$ From this perspective, then, biopolitics and sovereign power, rather than having a diachronic relation, are equally old ${ }^{108}$ and 'the production of a biopolitical body is the original activity of sovereign power'. ${ }^{109}$ Moreover, the classical Aristotelian distinction between the political form of life, endowed with rights (bios) and the bare animal life (zoe) collapses.

Agamben's thought on biopolitics hinges on what he calls bare life. Bare life is indeed the 'protagonist' of biopolitics. ${ }^{110}$ The 'decisive fact' of biopolitics is precisely that 'the realm of bare life [...] gradually begins to coincide with the political realm'. ${ }^{111}$ Yet bare life while included within the political and juridical realm, is in the very same gesture also excluded.

\footnotetext{
${ }^{104}$ Agamben (n 19) 11.

105 Esposito speaks in this respect of a semantic and conceptual 'slippage' that one can find in Foucault, which maintains a certain linguistic mobility or uncertainty, and speaks of a replacement or substitution as well as a complementation, Esposito (n 20) 39-40.

${ }^{106}$ Roberto Esposito, 'Community, Immunity, Biopolitics' (2013) 18 Angelaki, 83, 86.

107 Agamben (n 19) 11.

108 ibid 11.

109 ibid 11 , emphasis in the original.

110 ibid 12.

111 ibid 12.
} 
Neither a political body, nor a natural one, bare life remains thus trapped in what he calls a 'zone of irreducible indistinction'. ${ }^{112}$ This zone is governed through the suspension of the rule of law and the normalization of a state of exception. Like the home sacer of Roman origin, bare life can be killed with impunity, as it no longer belongs to the political order, yet it is not 'indifferent to law'. ${ }^{113}$ Indeed, by enacting its own suspension, law seizes living beings under its power. ${ }^{114}$ This is the paradox of biopolitics for Agamben: bare life is included in the juridical order through its exclusion, ${ }^{115}$ and is thrown into a site where inclusion and exclusion, law and violence, life and death, the political form of life endowed with rights and the bare life, which can be killed with impunity, co-exist simultaneously.

Esposito, as mentioned, also emphasizes the continuity between sovereignty and biopolitics. Esposito speaks in fact of a 'logic of copresence', and even of a 'secret and essential' relation between sovereignty and biopolitics. ${ }^{116}$ To understand Esposito's concept of immunity, one must start from the concept of community. ${ }^{117}$ Esposito carries out a genealogical reconstruction of the concept of community, and emphasizes the munus, that is the duty, the burden, that a community poses on individual members. As Esposito put it, 'to belong entirely to the originary communitas means to give up one's most precious substance, namely, one's individual identity'. ${ }^{118}$ From this starting point, where individuals gradually open (and lose) themselves to the communal, Esposito constructs the concept of immunity: if community, in fact, 'is what binds its members in a commitment of giving from one to the other', immunity is a strategic reversal whereby individuals 'unburden' themselves from the communal burden, 'exonerate' themselves from the communal responsibility. ${ }^{119}$ If the community penetrates and deconstruct the 'barriers of individual identity' then, immunity by contrast is the necessary strategy rebuilding those barriers 'in defensive and offensive forms, against any external element that threatens it'. ${ }^{120}$ Immunity, moreover, can take also a collective character, where particular communities immunize themselves against any external threat.

\footnotetext{
112 Ibid 12.

113 Amy O'Donoghue, 'Sovereign Exception: Notes on the Thought of Giorgio Agamben', (Critical Legal Thinking 2 July 2015) <http://criticallegalthinking.com/2015/07/02/sovereign-exception-notes-on-the-thought-of-giorgioagamben/> 'accessed on 5 June 2018.

${ }^{114}$ Giorgio Agamben, State of Exception (University of Chicago Press 2005) 3.

115 O'Donoghue (n 106). See also, of course, Agamben (n 19) 18.

116 Esposito (n 20) 40.

${ }^{117}$ See eg Esposito (n 106).

118 ibid 84.

119 ibid 84.

120 ibid 85 .
} 
Immunity is thus, for Esposito, the crucial interpretative key of biopolitics, the fundamental mechanism of modernity, the key hinge in the inextricable relation between life and power. Immunity indeed is conceived as the 'constitutive nexus' between the negative and positive aspects of biopolitics. ${ }^{121}$ Here is expedient to quote Esposito at length:

In its dual appearance in the legal and biological realms, this paradigm is the exact point of tangency between the spheres of life and politics. This is where the possibility arises of filling the gap in principle between the two extreme interpretations of biopolitics - between its deadly version and its euphoric version. Instead of two opposing, irreconcilable ways of understanding the category, they constitute two internal possibilities, in a horizon that is unified precisely by the bivalent character of the immune dispositif, which is both positive and negative, protective and destructive. ${ }^{122}$

Immunization becomes thus for Esposito the key mechanism through which sovereignty and biopower remain entangled with one another in an intimate relation that ends up producing an aporetic logic from which, apparently, there is no possibility of escape. Immunization is precisely the biopolitical mechanism through which, paradoxically, life protects itself from its own excesses. ${ }^{123}$ Immunization keeps at bay all chaotic, dangerous, exuberantly biological and animal impulses, thus protecting the newly constructed modern subject from all those communitarian obligations that negate, by crossing it, the threshold of the individual autonomy so central to the socio-cultural paradigm of modernity. It is however precisely at this point that the immunitary trajectory shows its aporetic logic, as the protection of life turns out to be also the protection from life. This relationship always maintains itself on the brink of a paradox to the extent that in order to protect itself, life must submit to a power that is capable of interdicting life's own development. ${ }^{124}$

This paradox is evident in the paradigmatic Hobbesian model where men, in order to protect their life from the effects of the war of all against all, must submit to the command of the sovereign, who in turn can justly kill them in order, paradoxically, to protect them (or, rather, kill some to protect others). Esposito indeed underlines the 'necessary link' that exists between the goal of 'the preservation of life with the possibility - always present even if rarely utilized - of the taking of life by the one who is also charged with insuring it'. ${ }^{125}$

\footnotetext{
121 ibid 86.

122 ibid 86.

123 ibid 86.

${ }^{124}$ Esposito (n 20) 56.

125 ibid 62.
} 


\subsection{Conservation: Expanding Biopolitics to Nature}

The preceding section offered an outline of biopower, biopolitics and of the two key elaborations Agamben and Esposito provided through the concepts of bare life and immunity. This section will briefly show how this biopolitical framework can be fruitfully applied, in two ways, to nature and natural processes. Expanding the biopolitical framework to nature will in turn enable a biopolitical critique of the regulation of invasive alien species. Indeed, this will be my argument, international law categorizes invasive alien species as bare nature precisely in Agamben's sense, and this categorization is justified by the immunitary logic aimed at protecting life from its own problematic, destructive excesses.

Biopolitics enfolds nature in its logic in two distinct but complementary ways: first as a set of processes central to human well-being, to the extent that human populations are affected in multiple ways by the environment they live in and by natural processes; secondly, as the immediate focus of concern. From this second perspective, which is the most relevant in the context of this article, biopolitics aims at the protection, regularization and optimization of nature itself. ${ }^{126}$ A chief mechanism that operationalizes this second perspective is precisely (international) environmental law.

Furthermore, and in line with Foucault's insight of the co-implicated relation between power and forms of knowledge, ${ }^{127}$ the expansion of biopolitical regimes to the natural environment is historically contingent on the development of a number of scientific disciplines such as biology and ecology, as well as on a number of technologies and techniques that allow the monitoring of ecosystem processes. This is what Foucault called the panopticist gaze of biopolitics. ${ }^{128}$ Ecology in particular plays a crucial part, as it 'provided the political technology for new forms of regulatory intervention in the management of the population and resources'. ${ }^{129}$ These new forms of intervention, Rutherford for example observes, combine to 'constitute a form of ecological governmentality', ${ }^{130}$ or as others suggest, an 'ecopolitics', ${ }^{131}$ or an 'ecopower'. ${ }^{132}$

\footnotetext{
${ }^{126}$ See eg Paul Rutherford 'The Entry of Life into History' in Eric Darier, (ed) Discourses of the Environment, (Blackwell 1999). For a more detailed account of these two distinct but complementary perspectives see De Lucia (n 15).

${ }^{127}$ See eg Michel Foucault, Discipline and Punish. The Birth of the Prison (2nd ed, Vintage Books 1995) esp. 2728.

${ }^{128}$ From Bentham's idea of the Panopticon, a building design that enabled the surveillance of all inmates of a particular intuition by one man, without the inmates being able to know when they are being watched.

${ }^{129}$ Paul Rutherford, The Problem of Nature in Contemporary Social Theory (PhD Thesis, The Australian National University 2000) 4.

130 ibid 4

${ }^{131}$ Eric Darier, 'Foucault and the Environment: An Introduction' in Darier (n 126) 23.

${ }_{132}$ Paul Lascoumes, L'éco-pouvoir Environnements et Politiques (La Découverte 1994).
} 
Environmental law, from this perspective, becomes a crucial juncture where knowledge and power intersect and coalesce into a regulatory framework aimed precisely at protecting, regularizing and optimizing nature, particularly through the double goal of conservation and sustainable use of biological diversity.

It is not necessary to linger further on this ecological declension of biopolitics if not to underline how the mechanics of immunization that Esposito delineates are operative in relation to any threat to a particular community. From an ecological point of view then - and as a combination of the two perspectives through which biopolitics can be expanded to nature - immunitary responses are a key strategy for the protection of nature, and more specifically, for the protection of biodiversity, against any potential threat. The next section will discuss the strategy of immunization against biological threats to biodiversity posed by invasive alien species, and the aporetic logic that will be the primary target of my biopolitical critique.

\section{Biopolitical Law: Protecting Life through Killing Life}

\subsection{Ecological 'Racism' and the Immunitary Logic of Biopolitics}

We have seen so far how immunization underpins, as a justificatory logic, the regulatory interventions against any threats to biodiversity. We have also seen that invasive alien species are considered one of the 'primary threats' to biodiversity. ${ }^{133}$ The key preliminary operation in this sense is the conceptual delineation and definition of the notion of invasive alien species. Only then species can be discerned, arrayed, categorized. Indeed, the delineation of partitions, boundaries, categories, is a typical legal operation, whose effects are concretely inscribed on living bodies. The categorization of a life form as an invasive alien species is in this respect the crucial move - simultaneously juridical and biopolitical - through which certain life is fully delineated and certain species are transformed into bare nature.

The consequences of this immunitary $\operatorname{logic}^{134}$ are discussed by Foucault in terms of racism. Foucault understands racism as a process of differentiation, as 'a way of introducing a break into the domain of life that is under power's control: the break between what must live and what must die'. ${ }^{135}$ The function of this racism, for Foucault, is 'to fragment, to create caesuras within the biological continuum addressed by biopower'. ${ }^{136}$ In the context of this article, we could speak more specifically of an ecological racism traversing the international legal framework

\footnotetext{
${ }^{133}$ Decision VI/23 (n 37) para 1 Section II.

${ }^{134}$ Whose most spectacular effects are concretized in the Nazi concentration camps. The latter is for Agamben the paradigmatic horizon of modernity, Agamben (n 17); the Nazi camp is generally a central theme of the biopolitical literature, see for example, Esposito (n 20) and Campbell and Sitze (n 84).

${ }^{135}$ Foucault (n 89) 254.

136 ibid 255.
} 
regulating invasive alien species, and operationalized through those biopolitical interventions that simultaneously protect biodiversity (that is, native life and natural ecosystems) and eradicate biological threats (invasive alien species).

As mentioned, a key mechanism in the operationalization of the logic of biopolitics is categorization. This categorization operates at two levels. First, once particular species are categorized as invasive alien species, the matrix of provisions that regulates them becomes applicable. Species thus categorized can be lawfully eradicated, controlled and/or contained, or, using a biopolitical vocabulary, subjugated, disciplined and killed. Through the second level of operation of this categorization, more specifically biopolitical, such species become effectively 'bare nature' in the Agambenian sense outlined above. That is, they are thrown in that zone of indistinction where life-affirming and life-negating practices coincide and conflagrate. Under the label 'biosecurity' ${ }^{137}$ then - a label that conveys the imperative to protect life from life's own uncontrolled, undisciplined excesses through its eradication - the underlying immunitary character of biopolitics further emphasizes the deep entanglement that, Esposito suggests, exists between biopolitics and the sovereign paradigm of modernity. ${ }^{138}$ The sovereign command enables and underpins the biopolitical discernment, while the biopolitical discernment legitimizes the sovereign command.

But there is a second aspect, or function of racism that is of interest for the purposes of this article, provided the term 'racism' is not taken entirely at face value, ${ }^{139}$ but rather understood in terms of its logic, a logic that, I argue, can be seen at work in relation to invasive aliens species. This second function relates even more directly to the immunitary logic that Esposito identifies at the core of modernity. Racism, suggests Foucault, has a 'vital importance'140 to the exercise of a power which, both conceptually and operatively, conjoins sovereign power

${ }^{137}$ See eg Michael Jeffery, Jeremy Firestone and Karen Bubna-Litic (eds) Biodiversity Conservation, Law and Livelihoods: Bridging the North-South Divide (Cambridge UP 2008). The entire Part IV is entitled 'Biosecurity Issues', and Section A of Part IV is dedicated to Alien Species. A few other examples (out of a large literature) from a variety of disciplinary perspectives sufficiently illustrate how the biopolitical dispositif operates through the concept of alien species and the frame of biosecurity: Karen Armstrong and S Ball, 'DNA Barcodes for Biosecurity: Invasive Species Identification' (2005) 360:1462 Philosophical Transactions of the Royal Society, 1813; Bax and others (n 3); LM Humble and EA Allen, 'Forest Biosecurity: Alien Invasive Species and Vectored Organisms' (2006) 28:S1 Canadian Journal of Plant Pathology 256.

${ }^{138}$ Indeed, the frame of security is a central element in the biopolitical articulation of biopower, as Foucault discusses at length in the Security, Territory and Population lectures series, Foucault (n 89) There is however no space for discussing the biosecurity discourse from the Foucauldian point of view developed, as a preliminary articulation of biopolitics precisely from an immunitary angle, and despite the great additional depth that discussion would add to this analysis.

139 That is, its literal meaning of 'Prejudice, discrimination, or antagonism directed against someone of a different race based on the belief that one's own race is superior', Oxford Dictionaries Online, <https://en.oxforddictionaries.com/definition/racism> accessed on 6 June, 2018

${ }^{140}$ Foucault (n 89) 256. 
and biopower. Racism is situated in fact at their intersection, further consolidating the argument for a fundamental continuity, or even intimacy, between the two modes of power, and hence for the fundamentally biopolitical character of modernity. In this sense, racism is the 'indispensable precondition' ${ }^{141}$ for any form of direct and indirect 'killing' as an exercise of sovereign power, to the extent that any killing must be justified in biological terms, that is, in relation to the biopolitical goals of the elimination of biological threats to humans or, more importantly in the context of this article, to biodiversity.

\subsection{Revisiting the International Legal Framework Regulating Invasive Alien Species}

It is at this point possible and useful to revisit (and expand on) some of the key international legal provisions regulating invasive alien species presented in section 2 . This will help appreciate how biopolitics and the immunitary logic that underpins it, are operationalized through international environmental law in the name of protecting biodiversity. ${ }^{142}$ In section 2 we have spent some time exploring the rules and principles regulating invasive alien species. The CBD in particular has been the focus of sustained attention, given its significance in relation to invasive alien species, so it is the best place to start in order to illustrate, in light of the theoretical framework outlined in section 3, how the CBD indeed articulates a biopolitical logic. Article 8(h), as we have seen central in relation to the regulation of invasive alien species, obliges Parties to prevent the introduction of alien species and to 'control or eradicate' those alien species 'which threaten ecosystems, habitats or species'. ${ }^{143}$ As regards prevention, a key principle that should be followed by State parties to the CBD in the fight against invasive alien species sets out that States should implement 'border controls and quarantine measures for alien species that are or could become invasive'. ${ }^{144}$ If prevention is not possible however, as explained by the mentioned CBD COP decision VI/23, eradication is the best strategy. Indeed, if feasible, eradication is precisely 'the best course of action' ${ }^{145}$ For the purposes of eradication, detection and monitoring mechanisms are key as the

best opportunity for eradicating invasive alien species is in the early stages of invasion, when populations are small and localized; hence, early detection systems focused on highrisk entry points can be critically useful while post-eradication monitoring may be

\footnotetext{
141 ibid 256.

${ }^{142}$ It must be noted that the biopolitical discernment between good, productive species and bad, noxious, threatening or damaging ones can be traced back very early, to the 1902 Convention for the Protection of Birds Useful to Agriculture which, as already mentioned in the introduction, distinguishes indeed between useful and noxious birds, hence discerning between which life to protect and which to eliminate.

${ }^{143}$ CBD (n 27), Article 8(h), emphasis mine.

${ }^{144}$ Decision VI/23 (n 37) Annex Section B, Principle 7.

145 ibid Annex Section D, Principle 13, emphasis mine.
} 
necessary. Community support is often essential to achieve success in eradication work, and is particularly effective when developed through consultation. ${ }^{146}$

If eradication is not possible, containment ${ }^{147}$ and control ${ }^{148}$ are the next best strategies available against the biological invasion - and here the choice of language is arguably very important of invasive alien species. Containment and control strategies also require continuous and comprehensive monitoring.

These monitoring mechanisms that are required to support both eradications and containment and control, enact precisely that biopolitical panoptical gaze necessary for the constant surveillance of threats to biodiversity, in order to ensure biosecurity. Monitoring, which as we have seen is 'key to early detection of new invasive alien species', ${ }^{149}$ takes a multiplicity of forms and implement a diversity of surveillance strategies, including the development of global databases such as IUCN's Global Invasive Species Database, the utilization of costly mathematical tools such as habitat suitability models, ${ }^{150}$ and even the involvement of local communities. Local communities involvement include the participation of 'citizen scientists' as well as other participatory mechanisms ${ }^{151}$ in ways that harness local communities as 'environmental managers' ${ }^{152}$ that contribute to the production of the double biopolitical effect of nurturing and subjugating nature. ${ }^{153}$

The Global Invasive Species Programme was in this respect a central mechanism, though it has been discontinued in 2011 for lack of funding caused by the global economic recession (or rather it 'entered a dormant phase'). ${ }^{154}$ There also exist a Global Invasive Species Database (GISD), whose purpose is to offer free information on all invasive alien species for which data exists. The GISD, has been set up and is managed by IUCN's Invasive Species Specialist Group, and also 'aims to increase public awareness about invasive species and to facilitate effective prevention and management activities by disseminating specialist's knowledge and

\footnotetext{
146 ibid Annex Section D, Principle 13.

147 ibid Annex Section D, Principle 14.

148 ibid Annex Section D, Principle 15.

149 ibid Annex, Section A, Principle 5.

${ }^{150}$ See AW Crall and others, 'Using Habitat Suitability Models to Target Invasive Plant Species Surveys', (2013) 23 Ecological Applications 60.

${ }^{151}$ Such as the utilization of specific phone apps (available for download on both Google Play and iTunes) to allow citizens to report sightings of invasive alien species

152 Andreas Kotsakis, The Biological Diversity Complex: A History of Environmental Government (PhD Thesis, London School of Economics 2011).

${ }^{153}$ See more in general ibid, esp. chapter 7, 'Governing in the Biocomplex II: The Participation of Local and Indigenous Communities'.

${ }^{154}$ See Sarah Simons, 'Closure of the Global Invasive Species Programme' BCGI Resources Centre 13 April 2011), <www.bgci.org/resources/news/0794> accessed 5 June 2018.
} 
experience to a broad global audience'. ${ }^{155}$ The GISD ultimately provides information management and dissemination that shall help and support practitioners, conservation managers and policy-makers in managing invasive alien species. ${ }^{156}$

Finally, a Global Invasive Alien Species Information Partnership (GIASIP) was set up under the CBD. The GIASIP is a 'mechanism through which invasive alien species information users and providers can collaborate in a timely and effective manner', ${ }^{157}$ and its purpose is to facilitate implementation of article 8(h), as well as to help achieve Aichi Target 9.

The rules and principles that regulate invasive alien species are contained also in a number of other international legal instruments related to biodiversity, as we have seen in section 2 . These contribute to a rather coherent and consistent legal framework, and likewise reproduce the same biopolitical logic underpinning the CBD. All of them insist on the tripartite goal of prevention, control and eradication, tough we shall now revisit only some of them.

The Ramsar Convention, for example, considers, as we have seen, the preparation of programmes of control and eradication of priority invasive alien species as a key strategy. ${ }^{158}$ In that respect, the review of existing laws and the preparation of new ones is an important element. Law is clearly central for any biopolitical strategy, as it provides a legitimate (legal, as it were) basis for surveillance and for eradicating unwelcomed and invasive life.

Within the context of the CMS, ACAP adopted, as we have seen, 'Guidelines for eradication of introduced mammals from breeding sites of ACAP-listed seabirds'. ${ }^{159}$ These guidelines lay out the framework for carrying out eradications. They start by reviewing the main methods for eradication of different species. Rodents are usually killed by poisoning, rabbits by poisoning, shooting and detection by dogs, ungulates by shooting, cats by trapping, shooting, poisoning and detection by dogs. ${ }^{160}$ With particular respect to poisoning however, the report continues, a 'multiyear follow up phase is critical after poisoning, particularly as it is unlikely that aerial broadcast of baits will kill all target individuals for rabbits and cats'. ${ }^{161}$ These guidelines establish thusly best practices and guide, as it were, domestic implementation of programmes of eradication of invasive alien species of state parties to ACAP.

\footnotetext{
155 <www.iucngisd.org/gisd/about.php> accessed 5 June 2018. For further info on GISD see Shyama Pagad and others, 'IUCN SSC Invasive Species Specialist Group: Invasive Alien Species Information Management Supporting Practitioners, Policy Makers and Decision Takers', (2015) 6 Management of Biological Invasions 127. ${ }^{156}$ Pagad and others (n 155).

157 COP 'Operational Plan for Global Invasive Alien Species Information Partnership', Note by the Executive Secretary, 2012, UNEP/CBD/COP/11/INF/34, para 3.

${ }^{158}$ See eg Resolution VII.14 8 (n 33) and VIII.18 (n 33)

${ }^{159}$ Phillips (n 72).

160 ibid 4.

161 ibid 4.
} 
Revisiting these provisions in light of the theoretical framework presented in section 3, has arguably helped to show how they can all be read as biopolitical markers, or even as biopolitical tools. It further showed how law enables, facilitates and legitimizes the operationalization of the biopolitical and immunitary logic whereby life is protected through the production of death, and death is legitimated by the protection of life. To further and more vividly illustrate how the biopolitical aporia operates on the ground, on the very bodies of individuals of invasive alien species, it will now expedient to discuss some concrete examples of eradication projects that were carried out in order to implement the global and regional international goals, principles and rules we have discussed thus far.

\subsection{Bare Nature: Enacting the Biopolitical Aporia}

This section will show concrete examples of how conservation may proceed by way of mass killings, in order to remove biological threats to life. Indeed, whether by poisoning or by sniper fire, life is routinely killed in the name of protecting life. This subsection will offer some example in order to illustrate the concrete details of eradication activities, and how they arguably enact precisely the biopolitical aporia I have discussed in this article. These interventions aimed at punishing 'life-disrupting life', ${ }^{162}$ embody precisely the biopolitical logic in the context of conservation by arbitrating 'the classification of life into species and populations', a preliminary operation necessary to then decide 'whom to correct and whom to punish [...] who shall live and who shall die, what life-forms will be promoted and which will be terminated'. 163

A first example capable of illustrating the immunitary logic of the regulation of invasive alien species at work (one moreover linked to ACAP, as it at least partly implements obligations laid out therein), is the Macquarie Island Pest Eradication Project. Macquarie Island, an Australian island located in the South West Pacific, is a World Heritage site ${ }^{164}$ whose conservation status was severely threatened by a number of invasive species. Rabbits in particular, introduced in 1880 as food source for seal and penguin hunters, had very damaging effects on grasslands. Rodents, and especially the black rat, also had significant damaging effects, as they would prey on chicks and eggs of burrow-nesting petrels (which makes this project fall under ACAP). The choice of eradication (as opposed to control) was based on a number of reasons. Most

\footnotetext{
${ }^{162}$ Christine Biermann and Becky Mansfield, 'Biodiversity, Purity, and Death: Conservation Biology as Biopolitics' (2014) 32 Environment and Planning D: Society and Space 257, 261.

163 ibid 261.

${ }^{164}$ UNESCO Decision : CONF 208 VIII.A, 'Macquarie Island', 629 Rev.Australia, N(i)(iii).
} 
interesting for the purposes of this article is that eradication was considered the optimal strategy because it is 'the only way to protect the long-term integrity of native fauna, flora and other natural values' of the island. ${ }^{165}$ In other (biopolitical and immunitary) words, the best way to foster (native) life is to kill (invasive alien) life. The plan targeted three species: the European rabbit, the black rat, and the house mouse. ${ }^{166}$

The method utilized in the eradication project on Macquarie Island was twofold. The first step was aerial baiting of the entire island with poisoned pellets. Subsequently, intensive monitoring by hunters and highly trained detection dogs would follow, in order to detect and dispatch any individuals who had survived the poisoned bait, ${ }^{167}$ in line with ACAP's guidelines and recognized best practices. The project was declared successfully concluded in $2014 .{ }^{168}$ It is interesting to read some extracts from the report of the Macquarie Project newsletter. ${ }^{169}$ The newsletter underlined how the project killed all of an estimated 150000 rabbits and an unknown number of rodents. It further highlighted how, after the aerial baiting, the on-theground teams of hunters and dogs began an extensive and intense search for any surviving individuals in order to kill them off. Within the next four months, 8 surviving rabbits were found and killed, plus a litter of juveniles. Further, 'In the nearly three years since baiting was completed (ie in 2011), the hunters and dogs have scoured the island thoroughly, searching day and night for any sign of surviving individuals of the three pest species'. ${ }^{170}$ The success is ultimately validated by the results that 'are visible all around the island, whether it be by the amount of vegetation growing back, seeing spider webs in the grass stalks on the plateau, moths around the island or the increased numbers of blue petrel burrows'. ${ }^{171}$ Indeed, 'everyone familiar with the island has been astounded and thrilled by the rapid rate of vegetation regrowth'. ${ }^{172}$ (Native) life thrives again, as (invasive and alien) life was eradicated.

Having successfully completed the eradication project, the next point on the agenda is the prevention of future biological invasions. Prevention protocols, such as screening and multiple

\footnotetext{
165 'Plan for the Eradication of Rabbits and Rodents on Subantarctic Macquarie Island' (Macquarie Plan), Parks and Wildlife Service Department of Tourism, Arts and the Environment, Tasmania, 2007, 13, <www.environment.gov.au/system/files/resources/204dda05-920a-4cf3-b60e-00b1f4425abe/files/macquarierabbit-eradication-plan.pdf> 'accessed 5 June 2018.

166 ibid.

167 ibid, Section C 'Eradication Methods', 12ff.

${ }^{168}$ See Macquarie Dispatch, Macquarie Island Pest Eradication Project Newsletter, Issue 14, July 2014, <www.parks.tas.gov.au/file.aspx?id=36472> accessed 5 June 2018, whose lead article was titled 'Success on Macquarie Island'.

169 ibid .

170 ibid 2 .

171 ibid 2.

172 ibid 3.
} 
quarantine barriers, are indeed understood as the key, and are framed in terms of biosecurity, an important biopolitical marker discussed in previous subsections under the headings of biopolitical surveillance. Indeed, as the newsletter highlights, 'enhanced biosecurity is the key to a pest-free future'. ${ }^{173}$ In this respect, 'a strict and comprehensive biosecurity program has been implemented by the Parks and Wildlife Service in conjunction with the Australian Antarctic Division (AAD) to prevent the reintroduction of rodents or the introduction of any new pest species'. ${ }^{174}$

A second case will further illustrate this biopolitical immunitary logic. This case regards species introduced to the Seychelles voluntarily as domestic pets. Those species, however, eventually escaped (or were set free) and subsequently established themselves and spread, threatening an island ecosystem particularly vulnerable to invasions. ${ }^{175}$ Red-whiskered bulbuls is one example. A species of birds, red-whiskered bulbuls were introduced in the 1970s by migrant miners as pets. Once escaped into the wild however, they spread and took hold, thus becoming a threat for a local bird species. A dramatic transformation from pets to pest threw thus the red-whiskered bulbul into the realm of bare nature. Red-whiskered bulbuls' invasion prompted indeed a radical response from biodiversity conservation managers, as their presence was identified as a threat to a native bulbul species. The native bulbul species however is located on a different island, Aldabra, 17 miles away. Aldabra is a biodiversity rich island that is both a special nature reserve under domestic legislation, ${ }^{176}$ and a UNESCO World Heritage site. ${ }^{177}$ The alien bulbul species had however managed to reach Aldabra once, so conservation managers would not take any risk, and decided for eradication. To date, all 5279 red-whiskered bulbuls have been killed by snipers. As eradication project leader Jessica Moumou observed, ' $[\mathrm{t}] \mathrm{o}$ protect the jewels, you have to repel the invaders'. ${ }^{178}$ This is precisely the logic of biopolitical racism at work: to protect (some) life, (some other) life must be killed.

This is not the only eradication project ongoing in the Seychelles. There are in fact several. One is related to another bird, the ring-necked parakeet. Also introduced as pets, as National Geographic reports, 'ring-necked parakeets escaped into the wild and now threaten the national

\footnotetext{
173 ibid 3.

174 ibid 3.

175 Kennedy Warne, 'In the Seychelles, Taking Aim at Nature's Bullies' National Geographic (1 March 2006) <www.nationalgeographic.com/magazine/2016/03/seychelles-islands-nature-reserve-national-parks/> accessed 5 June 2018.

${ }^{176}$ Under the Seychelles Natural Parks and Nature Conservancy Act, $15^{\text {th }}$ December 1969.

177 World Heritage Committee, Decision CONF 015 VIII.20, 'Nominations to the World Heritage List (inscribed sites)' (6 $6^{\text {th }}$ session, 1983).

178 Ibid.
} 
bird, the Seychelles black parrot, concentrated on Praslin island. Contract shooters are trying to wipe out the intruder'. ${ }^{179}$

These cases have illustrated how the biopolitical and immunitary logic I have described in this article operates concretely on the ground, in what manner, and what sort of questions it may, or should, raise. As the journalist reporting on the Seychelles eradication project indeed observed, '[k]illing a bird to save a bird may seem a perverse exchange — a misguided intrusion into nature's affairs'. ${ }^{180}$ The journalist raises also further and broader questions, questions however also crucially related to the biopolitical logic. When is killing a bird to save a bird justifiable? Is the recovery of various native species of birds worth the price of killing off another (invasive alien) species ${ }^{181}$ Is the uniqueness of saved species worth more than the lives of common species like house mice or common rabbits, especially when far from their 'original' habitat? When does human intervention becomes a 'misguided intrusion'? Humans are after all part of the ecosystems they manage. What is then the biopolitical threshold for intervention? Is there still a pristine nature that may function as a reference point to discriminate between legitimate intervention and intrusion? Arguably not. ${ }^{182}$ Or is rather the case, like new conservationists argue, ${ }^{183}$ that the distinction between natural and artificial no longer has any meaning, and therefore nature is inevitably 'a nature that we make'? ${ }^{184}$ If so, the question becomes rather 'the degree to which this molding will be intentional or unintentional, desirable or undesirable'. ${ }^{185}$ These are difficult questions, and cannot be addressed and explored here. It is then perhaps time to draw some tentative conclusions and chart further the map of intersections between biopolitics and environmental law.

\section{Conclusions}

Invasive alien species, we have seen, are widely considered a critical threat to biodiversity, and their regulation is accordingly considered widely an important strategy for the conservation of biodiversity. International regulation takes primarily the form of prevention, eradication and

\footnotetext{
179 Ibid.

180 Ibid.

181 This is not an entirely fair juxtaposition, I'll admit, as native species are often threatened or vulnerable species, while many of the invasive alien species are thriving in many locations other than the one where they are defined as invasive. The question however serves the purpose of prompting reflections on this internal dilemma all the same.

182 P Kareiva, M Marvier and R Lalasz "Conservation in the Anthropocene Beyond Solitude and Fragility” (2012) The Breakthrough

${ }^{183}$ See eg Michelle Marvier, 'New Conservation is True Conservation' (2013) 28 Conservation Biology 1; Michelle Marvier and Peter Kareiva, 'The Evidence and Values Underlying 'New Conservation', (2014) 29 Trends in Ecology and Evolution 3.

${ }^{184}$ Daniel Botkin, Discordant Harmonies: A New Ecology for the Twenty-first Century (OUP 1990) 193

185 ibid 193.
} 
control, though prevention is often extremely difficult to achieve, with eradication being considered, where feasible, 'often the best course of action'. ${ }^{186}$ In this article, I have however tried to problematize the international regulation of invasive alien species from the particular theoretical vantage of biopolitics, in order to show its underlying logic, its internal contradiction, its dilemma. The key question I raised was linked to what I have described as the biopolitical aporia that inhabits both the conceptual approach and the operational aspects of the international legal framework regulating invasive alien species: killing nature to save nature. The regulation of invasive alien species, I have argued, operates as a biopolitical mechanism that effectively transforms some nature into what, with Agamben, I have described as bare nature, that is, a nature that is thrown into a zone where life and death, law and violence become indistinguishable. Once nature becomes bare nature, it can be killed with impunity. Moreover, the killing takes place in the name of life, that is, with the purpose of protecting (some other) life. Biopolitics here intersects with and operationalize the sovereign command on a specifically biological and positive ground, through its decision on what life lives and what perishes. Biopolitics thus enacts an aporetic mechanics of transformation of a politics of life (biodiversity conservation) into a politics a death (invasive alien species eradication). Yet, in a circular paradox, even death only becomes possible (ie legitimate) if its effects are beneficial to life (or at least certain lives). ${ }^{187}$ From a biopolitical perspective this discernment between the positively, neutrally or negatively useful, operates according to a logic of racialization (as we have seen in section 4 ) - ie the decision about which species must live (or function, endure etc.) and which must die (be done without, disciplined, relocated, eradicated etc.).

It is at this point of conjunction, at this intersection of natural and unnatural, of useful and noxious, of life and death, that the immunitary paradigm that Esposito sees as the central mechanism underpinning modern biopolitics (and its inevitable underbelly that produces death to foster life), becomes most immediately operative. It is here, moreover, that the fostering inflection of biopower and the violent decision of the sovereign are most visibly intertwined, as the examples reviewed in section 4.3 have endeavoured to illustrate.

Another aspect that is useful to highlight in this concluding section, is a significant tension between competing visions of nature. If on the one hand in fact, an ecological perspective

\footnotetext{
186 'Decision VI/23 (n 37) 'Guiding Principles', Section D, Principle 13, emphasis added.

${ }^{187}$ It is perhaps useful to note how a biopolitical framework of analysis makes possible to move beyond the usual binary juxtaposition between anthropocentrism and ecocentrism, that pervades most environmental legal scholarship, see De Lucia (n 17).
} 
understands nature to be in a state of flux, with no fixed or objective naturalness, ${ }^{188}$ the vision underlying the regulation of invasive alien species is on the other arguably linked to a wish to maintain a natural status quo, where species distribution, location and interaction remains fixed. Of course, the demarcation line can be drawn in relation to the speed of change and other factors which indeed may make problematic the artificial (ie human induced) introduction of alien species in novel environments, evolutionarily unprepared for their invasion. But how is that different from natural variation, besides the human source? Doesn't this approach still conceive of humans as apart from nature, as artificial, external factors in the life of ecosystems? Yet, considering the deep and pervasive influence humanity is exerting on all Earth's ecosystems (which prompted the coinage of a new geological epoch: the Anthropocene), it is arguably warranted to single out the artificial (ie human) introduction of alien species as 'unnatural', as something to prevent or, if prevention is impossible, to eradicate. However, does this justify the systematic killing of sometimes significant populations of animals on what, ultimately, are immunitary grounds, privileging certain life based on the ideal, aesthetics or economic preferences of humans?

The question we are left with ultimately is whether it is possible, and how, to exit the biopolitical aporia. Whether alternatives exist, or can be imagined. Perhaps we cannot. Indeed the space for imagining such alternatives is increasingly narrower, as different regimes (Ramsar, CMS, the CBD) enter into cooperative agreements, adopt joint work programmes, and foster synergies and complementary strategies. ${ }^{189}$ These synergies will inevitably entrench the biopolitical logic underpinning the regulation of invasive alien species, and will consolidate eradication - that is, biopolitical killings premised on ecological racism - as a legitimate practice. ${ }^{190}$ But if we can imagine alternatives, that possibility hinges on remaining vigilant, and on questioning existing practices in order to avoid at all costs to naturalize and internalize biopolitical strategies that may, and indeed do, transform some nature into bare nature, and produce death through the same gestures aimed at protecting life.

\section{Acknowledgements}

\footnotetext{
${ }^{188}$ See eg David Cole and Laurie Yung (eds) Beyond Naturalness: Rethinking Park and Wilderness Stewardship In An Era Of Rapid Change (Island Press 2010).

189 See eg Strategy 1.9, objective 1.9v, Ramsar Convention Secretariat, The Ramsar Strategic Plan 2009-2015: Goals, strategies, and expectations for the Ramsar Convention's implementation for the period 2009 to 2015 (4th edition, vol. 21. Ramsar Convention Secretariat 2010); The $5^{\text {th }}$ Joint Work Plan (JWP) $2011-2020$ between the CBD and the Ramsar Convention; CMS, Resolution 10.21 "Synergies and Partnerships", UNEP/CMS/Resolution 10.21 .

${ }^{190}$ I am grateful to one of the anonymous reviewers for suggesting this point.
} 
I wish to thank the anonymous reviewers for their very helpful comments. 